\title{
Melek Information and Communications Technology (ICT) Pada Masyarakat Pedesaan Di Era Globalisasi
}

\author{
Anggun Tri Kurniawatik ${ }^{1}$, Khaerunnisa ${ }^{2}$, Tasya ${ }^{3}$
}

Prodi IImu Komunikasi, Fakultas IImu Komunikasi, Universitas Islam Nusantara

\begin{tabular}{|c|c|}
\hline ARTICLE INFO & ABSTRACT \\
\hline $\begin{array}{r}\text { Article history: } \\
\text { Received Nov 9, } 2021 \\
\text { Revised Nov 14, } 2021 \\
\text { Accepted Nov 23, } 2021\end{array}$ & \multirow{2}{*}{$\begin{array}{l}\text { The development of information and communication technology is } \\
\text { one form of the presence of the era of globalization. The faster the } \\
\text { development, the easier it is for someone to access information. } \\
\text { However, the inequality of technological developments can be felt in } \\
\text { places where internet access is difficult, such as in Ciakar Village. } \\
\text { With descriptive quantitative research, this research can see the } \\
\text { views of the people of Ciakar Village in facing the development of } \\
\text { information and communication technology. The development of ICT } \\
\text { is currently needed not only in the city but in the village as well, } \\
\text { because ICT literacy provides many benefits both in the economic, } \\
\text { social, cultural, political and so on. So that the development of ICT, } \\
\text { it must be felt evenly to find out how the conditions are happening in } \\
\text { our country. }\end{array}$} \\
\hline \multirow[t]{4}{*}{$\begin{array}{r}\text { Keywords: } \\
\text { Information and } \\
\text { Communications Technology } \\
\text { Literacy; } \\
\text { Rural Community; } \\
\text { Globalization Era. }\end{array}$} & \\
\hline & ABSTRAK \\
\hline & $\begin{array}{l}\text { Perkembangan teknologi informasi dan komunikasi merupakan } \\
\text { salah satu bentuk dari hadirnya era globalisasi. Semakin pesat } \\
\text { perkembangannya maka semakin mudah pula seseorang } \\
\text { mengakses suatu informasi. Namun, ketidakmerataan dari } \\
\text { perkembangan teknologi itu dapat dirasakan di suatu tempat yang } \\
\text { sulit mendapatkan akses internet seperti halnya di Desa Ciakar. } \\
\text { Dengan penelitian kuantitatif deskripsi, penelitian ini dapat melihat } \\
\text { pandangan masyarakat Desa Ciakar dalam menghadapi } \\
\text { perkembangan teknologi informasi dan komunikasi. Perkembangan } \\
\text { ICT saat ini sangat diperlukan tidak hanya di Kota saja akan tetapi } \\
\text { di Desa juga, karena melek ICT sangat banyak memberikan } \\
\text { manfaat baik itu dalam bidang perekonomian, sosial, budaya, politik } \\
\text { dan lain sebagainya. Sehingga berkembangnya ICT ini, harus dapat } \\
\text { dirasakan secara merata untuk mengetahui bagaimana kondisi } \\
\text { yang terjadi di negara kita }\end{array}$ \\
\hline & This is an open access article under the $C C B Y-N C$ license. \\
\hline \multicolumn{2}{|l|}{ Corresponding Author: } \\
\hline \multicolumn{2}{|c|}{$\begin{array}{l}\text { Anggun Tri Kurniawatik } \\
\text { Fakultas Ilmu Komunikasi, Prodi IImu Komunikasi } \\
\text { Universitas Islam Nusantara, } \\
\text { Jl. Soekarno-Hatta No.530, Kota Bandung, Jawa Barat } 40286 \\
\text { Email: trianggun3235@gmail.com }\end{array}$} \\
\hline
\end{tabular}

\section{PENDAHULUAN}

Globalisasi merupakan isu penting yang muncul pada beberapa dekade yang lalu, adanya era ini ditandai dengan semakin majunya perkembangan teknologi, informasi dan komunikasi. Adanya keterbukaan akses informasi dan transfer teknologi dari negara maju kepada negara sedang berkembang merupakan ciri masuknya era globalisasi di Indonesia (Robby Darwis Nasution, 2016). Pada era ini, sebuah negara dituntut untuk lebih terbuka terhadap informasi atau 
modernisasi yang berasal dari asing jika tidak menginginkan negaranya terasing dari pergulatan perdagangan bebas.

Globalisasi merujuk pada keseluruhan proses-proses sosial yang melibatkan perpindahan orang, komoditas (barang), kapital, pengetahuan, pemikiran, informasi, dari satu negara ke negara lain. Kajian mengenai global village tidak dapat dipisahkan dari globalisasi. Konsep global village dalam terminologi studi globalisasi seringkali disebut sebagai globality (Appadurai, 2006).

Kemajuan ilmu pengetahuan dan teknologi di masa sekarang telah perlahan mengubah wajah dunia dari jaman konvensional kearah pengembangan berbasis internet. Pada era ini, perubahan tentunya akan mengubah beberapa aspek kehidupan khususnya di Indonesia, dimana aspek sosial kemasyarakatan, ekonomi, pembangunan dan juga pendidikan akan menyesuaikan dengan perubahan tersebut. Globalisasi juga menyebabkan terjadinya kompleksitas isu dan nilai yang menyebar dan menjadi universal (Battersby and Siracusa 2009, 59). Menurut Nasution (2015) masuknya era baru ditandai dengan adanya perkembangan ilmu pengetahuan dan teknologi.

Information and Communications Technology (ICT) atau dikenal juga dengan istilah teknologi komunikasi dan informasi (TIK). ICT atau TIK adalah payung besar terminologi yang mencakup seluruh peralatan teknis untuk memproses dan menyampaikan informasi. TIK mencakup dua aspek yaitu teknologi informasi dan teknologi komunikasi. Teknologi informasi meliputi segala hal yang berkaitan dengan proses, penggunaan sebagai alat bantu, manipulasi, dan pengelolaan informasi. Sedangkan teknologi komunikasi adalah segala sesuatu yang berkaitan dengan penggunaan alat bantu untuk memproses dan mentransfer data dari perangkat yang satu ke lainnya (Wikipedia, 2019).

Menurut Rifqi Muntaqo (2017) Saat ini perkembangan teknologi dan informasi yang semakin pesat telah mempengaruhi segenap kehidupan kita dalam berbagai bentuk aplikasi. Kemajauan teknologi ini telah memberikan sumber informasi dan komunikasi yang amat luas dari apa yang telah dimiliki manusia. Istilah teknologi ini sering digunakan dalam dunia pendidikan dengan sebutan pendidikan teknologi, teknologi pendidikan, teknologi informasi, informasi dan tekonologi komunikasi, teknologi bidang pendidikan, tekonologi baru bidang pendidikan, keterampilan informasi, informasi buta aksara, dan informasi belajar. Keterampilan komputer, keterampilan komunikasi, komunikasi belajar, jelaslah kata terminologi ini sering membingungkan seringkali dikaitkan dengan perkembangan terminologi kata (Liliweri, 2011: 857).

Menurut riset Asosiasi Penyelenggara Jasa Internet Indonesia (APJII), dan didukung banyak sumber lainnya menyatakan bahwa penggunaan internet terbesar di Indonesia didominasi di wilayah Barat, yaitu khususnya di pulau Jawa. (Marius and Sapto, 2015). Hal ini mengakibatkan sebaran akses infomasi dan komunikasi tidak bisa merata atau dirasa sangat lambat untuk bisa terjangkau di wilayah-wilayah pinggiran seperti wilayah timur Indonesia. Desa terpencil adalah salah satu perhatian besar Negara untuk menjalankan program teknologi jaringan internet. Tri Sakti Nawacita Kabinet Kerja Joko Widodo memuat tiga hal yaitu, desa yang berdaulat dalam politik, berdikari dalam ekonomi, serta berkepribadian dalam budaya. (Kurniawan 2015, 13)

Dalam melakukan strategi pembangunan sosial dapat dicapai secara maksimal dengan memanfaatkan penggunaan Teknologi Informasi dan Komunikasi (TIK) yang saat ini semakin berkembang. Dengan penggunaan yang tepat terhadap TIK, khususnya akses terhadap internet akan mampu menjadi kunci dalam pertumbuhan ekonomi, pembangunan sosial, dan juga pemberdayaan kaum yang kurang beruntung serta akan menumbuhkan integrasi antara pembangunan sosial dan pertumbuhan ekonomi (Castells, 1999; Chen \& Wellman, 2005; Tisdell, 2015).

Salah satu contoh dari ketidakmerataan teknologi yaitu di Desa Ciakar, Purwakarta. Karena akses internet yang masih menjadi hal yang belum dirasakan sepenuhnya oleh seluruh lapisan masyarakat, terutama di pedesaan atau daerah terpencil. Akses internet masih sulit sekali dijangkau. Orang-orang di desa harus ini masih tertinggal dalam mengakses internet dan mendapat sebuah informasi terbaru. Kecepatan sinyalnya pun sangat berbeda dengan koneksi internet di kota, kecepatan di kota bisa lima kali lebih cepat dibandingkan koneksi di pedesaan. Masalah ini yang sering kali masih menjadi sebuah perbincangan. Banyak masyarakat desa yang mengeluhkan keadaan seperti ini. Ditambah untuk orang tua yang memiliki anak yang masih bersekolah, tentunya penggunaan internet sangat dibutuhkan untuk menambah pengetahuan dan 
wawasan anak-anaknya. Selain itu, akses internet yang minim pun menyebabkan masyarakat desa kurang akan informasi akan perkembangan teknologi, informasi dan komunikasi yang ada. Mereka masih acuh tak acuh dengan keadaan yang terjadi dinegara kita. Selain akses internet yang sulit didapat, ternyata masih banyak hal lainnya yang menjadi penyebab tertinggalnya teknologi, informasi dan komunikasi di pedesaan.

Selain itu, untuk menghindari ketimpangan pembangunan antara wilayah perkotaan dan pedesaan, tentunya harus dilakukan dilakukan dengan perubahan paradigma pembangunan pedesaan yang menggabungkan antara kemajuan teknologi infomasi dan komunikasi dengan kearifan lokal di mana keduanya akan saling menguatkan satu sama lain. Teknologi informasi dan komunikasi akan membuka akses pengetahuan dan kerjasama baik dengan wilayah lain ataupun dari negara lain, sedangkan kearifan lokal berfungsi sebagai ciri dari desa tersebut dengan desa yang lain atau bisa dikatakan juga sebagai corak alamiah dari suatu desa. Dengan perkembangan teknologi informasi yang saat ini dapat dengan mudah dijangkau oleh masyarakat diharapkan dapat menambahkan kesejahteraan masyarakat, mendorong perekonomian serta dapat mencerdaskan seluruh masyarakat di Indonesia.

\section{METODE PENELITIAN}

Jenis penelitian yang dilakukan adalah kuantitatif deskriptif. Kuantitatif deskriptif adalah jenis penelitian yang digunakan untuk menganalisis data dengan cara mendeskripsikan atau menggambarkan data yang telah terkumpul sebagaimana adanya. Sugiyono (2017:2) mengatakan bahwa, metode penelitian pada dasarnya merupakan ciri-ciri ilmiah untuk mendapatkan data dengan tujuan dan kegunaan tertentu. Metode yang digunakan dalam pendekatan kuantitatif. Pendekatan kuantitatif ini digunakan oleh peneliti untuk mengukur tingkat keberhasilan dalam pengaruh perhatian orang tua terhadap minat belajar siswa.

Menurut (Resseffendi 2010:33) mengatakan bahwa penelitian deskriptif adalah penelitian yang menggunakan observasi, wawancara atau angket mengenai keadaan sekarang ini, mengenai subjek yang sedang kita teliti. Melalui penelitian deskriptif ini peneliti akan memaparkan yang sebenarnya terjadi mengenai keadaan sekarang ini yang sedang diteliti.

Penelitian ini difokuskan dan dilakukan di Desa Ciakar, Purwakarta. Adapun yang akan menjadi subjek penelitian adalah masyarakat yang tinggal di pedesaan dengan kisaran usia 13-40 tahun. Penelitian ini dilakukan untuk membahas dan mengetahui bagaimana perkembangan ICT atau TIK yang ada di desa Ciakar. Teknik pengumpulan data dalam penelitian ini dilakukan dengan membagikan angket kepada masyarakat di desa Ciakar, purwakarta.

\section{HASIL DAN PEMBAHASAN}

Kemajuan ilmu pengetahuan dan teknologi dimasa sekarang ini secara perlahan telah mengubah wajah dunia dari jaman konvensional kearah pengembangan berbasis internet $\mathrm{Di}$ dalam perubahannya tentu akan mengubah arah beberapa aspek kehidupan khususnya di Indonesia, dimana aspek sosial kemasyarakatan, ekonomi, dan juga pendidikan akan menyesuaikan kepada perubahan tersebut. Sebab dari adanya globalisasi yaitu terjadinya kompleksitas isu dan nilai yang menyebar dan menjadi universal juga merupakan efek dari adanya perkembangan Teknologi Komunikasi dan Informasi kata (Battersby and Siracusa, 2009). Menurut Nasution (2015) masuknya era baru ditandai dengan adanya perkembangan ilmu pengetahuan dan teknologi. Perkembangan Teknologi Komunikasi dan Informasi melibatkan beberapa bidang, seperti faktorfaktor sosial, ekonomi, budaya, politik, gender, etnisitas, geografis dan demografis dan teknologi, yang satu sama lain saling berinteraksi dalam proses pembangunan. Setiap pembangunan menawarkan perubahan, yang dampaknya terhadap satu wilayah dengan wilayah lainnya boleh jadi akan berlainan, karena karateristik suatu wilayah dengan wilayah lain berlainan (Sitompul, 2009).

Dampak perkembangan ICT ini membawa banyak pengaruh positif juga negatif. Maksud dari pengaruh positif diantaranya seperti pertukaran sebuah informasi yang lebih mudah dan cepat, memudahkan pekerjaan, serta pekerjaan dapat dilakukan oleh satu orang lebih efektif dan efisien, masyarakat tidak perlu lagi membeli koran untuk mengetahui informasi mengenai berita, cukup dengan membuka internet, kita sudah dapat membaca berita melalui media online, dan tidak mengeluarkan biaya. Selain banyaknya pengaruh positif, adapun beberapa pengaru negatif yang 
ditimbulkan beberapa diantaranya yaitu manusia menjadi malas. Karena telah dimanjakan oleh teknologi, sehingga kita tidak perlu repot bertemu dengan seseorang, berkurangnya sosialisasi karena kurang proses tatap muka atau face to face karena pesatnya perkembangan alat komunikasi, hal ini dapat menyebabkan komunikasi menjadi hampa.

Perkembangan Teknologi, Komunikasi dan Informasi berkembang sangat pesat dan cepat diseluruh penjuru dunia. Namun, perkembangan ini memunculkan kekhawatiran semakin tingginya ketimpangan. Ketimpangan sendiri merupakan kondisi yang ada pada masyarakat dalam konteks tertentu, tidak memiliki kemampuan serta keterampilan dalam mendapatkan akses yang efisien terhadap informasi yang bersifat global. Peran ICT dalam pembangunan mengalami suatu perubahan kebijakan pemerataan di Indonesia.

Persoalan kesenjangan yang terjadi di Indonesia ini terus mengiringi perkembangan teknologi dan informasi. Bagi negara dunia ketiga, persoalan ini adalah cukup bahaya bagi pembangunan. Bahkan dinegara maju sekali pun, dengan masyarakat "melek" terhadap teknologi digital, hambatan dalam akses ICT masih saja terjadi. Untuk menghindari ketimbangan pembangunan antara wilayah perkotaan dan pedesaan, tentunya harus dilakukan perubahan paradigma pembangunan pedesaan yang menggabungkan kemajuan teknologi informasi dan komunikasi dengan kearifan lokal dimana keduanya tentu akan saling menguatkan satu sama lain. Namun, di Indonesia perkembangan ICT ini masih mengalami ketidakmerataan, dimana perkembangan didominasi oleh daerah perkotaan saja.

Akses menerima teknologi informasi dan komunikasi di pedesaan memang masih jauh dari kata merata. Ini disebabkan satu dan hal lain diantaranya adalah jarak yang jauh dari kota sebagai pusat teknologi informasi dan komunikasi yang belum memungkinkan atau belum bisa memaksimalkan pemerataan hal tersebut. Namun di era globalisasi ini rasanya menyayangkan jika penerimaan akses teknologi informasi dan komunikasi masih belum merata, mengingat mendapatkan akses informasi dan komunikasi merupakan hak sebagai warga negara mendapatkan hal yang sama. Masuknya era globalisasi seolah menuntut semua orang untuk melek akan perkembangan teknologi, informasi dan komunikasi.

Pentingnya melek teknologi, informasi dan komunikasi harus senantiasa diterapkan kepada seluruh masyarakat Indonesia, dimana negara kita tertinggal sangat jauh dengan negaranegara lainnya. Kesenjangan ICT di desa dapat dilihat dari belum meratanya infrastruktur dan ketersediaan sumber daya manusia, teknologi informasi dan komunikasi, yang berpengaruh terhadap pemanfaatan ICT di tingkat desa. Akibat menghadapi berbagai permasalahan terkait pembangunan dan keterbatasan infrastruktur, maka penggunaan dan pemanfaatan TIK tidak dijadikan prioritas utama oleh pemerintahan desa. Kondisi geografis merupakan persoalan yang dihadapi bangsa Indonesia, terutama terkait di negeri ini yang berupa kepulauan. Kondisi itu menyebabkan akses informasi belum mampu menjangkau seluruh wilayah kepulauan. Selain itu, kekurangan skill dan kurangnya pemanfaatan akan internet juga mempengaruhi adanya kesenjangaan ICT.

Ada beberapa contoh akibat adanya ketimpangan informasi digital yang terjadi di Indonesia diantaranya, sistem penerimaan siswa baru di beberapa kota sudah menggunakan sistem online, untuk kemudahan pengisian data dan menjaga transparasi, calon siswa baru didaerah haru memahami prosedurnya sehingga tidak melakukan kesalahan dengan sistem online. Namun, di daerah pedesan sistem online masih banyak menggunakan sistem yang manual. Contoh lainnya yaitu mengenai peluang usaha atau pemasaran produk. Era informasi semakin memudahkan masyarakat dalam memenuhi kebutuhan hidup. Selain itu munculnya komunitas yang bernama netizen merupakan contoh dari adanya pekembangan teknologi. Kelompok ini merupakan pengguna internet yang berpartisipasi aktif. Melalu gadget atau smartphone yang dimiliki memberti kontribusi informasi secar positif bagi masyarakat dibidang ekonomi, politik, hukum dan budaya.

Dari tahun ketahun perkembangan ICT kian pesat. Ketidaksiapan dan ketidaksigapan kita menyongsong inovasi teknologi terutama dibidang ekonomi akan semakin tertinggal, dan persoalan-persoalan mendasar ekonomi pun semakin menggurita. Harapan bersama kita bahwa ekonomi digital ditahun-tahun yang akan datang harus mampu menyikapi berbagai persoalan mendasar yang selama ini cukup dituntaskan. Tipe penduduk negara-negara berkembang dengan tingkat pendidikan yang turut menyulitkan deminasi teknologi juga turut mempengaruhi suatu 
ketimpangan. Selain itu, persoalan ini menyoal literasi adalah pemanfaatan teknologi yang tidak tepat guna. Rendahnya literasi teknologi merupakan salah satu buntut dari persoalan ketersediaan infrastruktur teknologi yang minim. Bagimana orang memiliki peralatan teknologi jiga infrastruktur pendukungnya terbatas. Implikasinya adalah literasi teknologi yang rendah semakin langgeng. Rendahnya literasi teknologi ini jika tidak dijembatani dengan baik akan melanggengkan kondisi ketimpangan. Bahkan akan tercipta ketimpangan ICT semakin besar. Akibat yang akan muncul diantaranya banyak sekali pengangguran dan kemiskinan semakin sulit.

Melek teknologi, informasi dan komunikasi sangat diperlukan untuk era saat ini. Apalagi pada generasi 4.0 semua orang seperti dituntut untuk memunculkan inovasi-inovasi, menjadi kaum yang intelek dan menjadi generasi yang cerdas. Banyak sekali keuntungan yang bisa didapat ketika kita melek teknologi, informasi dan komunikasi, diantaranya mampu membuat pekerjaan manusia lebih ringan dan mudah sehingga bisa memaksimalkan prokduktivitas, kemudahan akses dalam mencari informasi, menghadirkan banyak inovasi, menghemat biaya, serta dapat menghemat waktu.

Ada beberapa upaya yang bisa dilakukan oleh pemerintah agar daerah pedesaan mampu melek teknologi, informasi dan komunikasi. Pertama, pemerintah bisa membangun infrastruktur yang memadai serta berkembang secara merata. Pembangunan Infrstruktur yang memadai dapat membuka peluang untuk masyarakat dalam meningkatkanpemanfaatan teknologi dan penguasaan. Dengan adanya pembangunan infrastruktur teknologi juga menjamin setiap orang agar dapat terhubung kedalam suatu jaringan. Maka dari itu, peluang untuk memanfaatkan akses pada ekonomi digital semakin terbuka. Kedua, melakukan pengenalan teknologi kepada masyarakat. Masyarakat seyoginya diberi fasilitas untuk memahami apapun mengenai teknologi digital. Misalnya bagi para pelaku UMKM, pengenalan terhadap marketplace berbasis digital sangat penting. Juga di lingkungan pendidikan, literasi teknologi sangat dibutuhkan dikarenakan untuk mengubah kecenderungan pamakaian teknologi bukan hanya untuk bermedia sosial. Ketiga, adanya payung ukur sebagai impasi ekonomi. Pemerintah seharusnya menyediakan perangkat hukum yang jelas pada berbagai inovasi digital. Tujuannya untuk menjamin adanya keamanan dan kenyamanan pelaku ekonomi dalam melakukan transaksi. Maka dari itu, perkembangan teknologi informasi dan komunikasi yang semakin pesat dalam usaha mengefektifkan layanan kepada masyarakat harus dilakukan sampai pada tingkat Desa. Keberadaan ICT selain dapat meningkatkan pelayanan juga bermanfaat dalam proses pengolahan data yang dapat juga digunakan untuk perencanaan pembangunan, mendukung pengambilan keputusan. Tujuan kajian ini adalah untuk mengidentifikasi kesiapan penerapan TIK dilihat dari aspek sumber daya manusia, sarana dan prasarana, kelembagaan dan anggaran dan menilai pelayanan melalui IT yang telah di lakukan.

Untuk mengetahui bagaimana Melek ICT pada Masyarakat Pedesaan khususnya di desa Ciakar, Purwakarta. Maka peneliti mengajukan beberapa pertanyaan yang sangat relavan untuk diisi secara jujur oleh responden yang secara sukarela mau mengisi kuesioner yang sudah disiapkan. Berikut ini beberapa pernyataan yang diajukan kepada responden:

Tabel 1. Daftar pernyataan yang diajukan kepada responden

\begin{tabular}{|c|c|c|c|c|}
\hline No & Pernyataan & $\mathbf{S}$ & $\mathbf{R}$ & $\mathbf{T}$ \\
\hline 1. & $\begin{array}{l}\text { Adanya teknologi informasi dan komunikasi memudahkan kita mengakses } \\
\text { apapun baik informasi, pembelajaran dan lain-lain. }\end{array}$ & 29 & 1 & 0 \\
\hline 2. & \multirow{2}{*}{$\begin{array}{l}\text { Teknologi informasi dan komunikasi berkembang dengan sangat pesat. } \\
\text { Pedesaan merupakan salah satu aspek yang perkembangan teknologinya } \\
\text { cepat. }\end{array}$} & 21 & 9 & 0 \\
\hline 3. & & 1 & 6 & 23 \\
\hline 4. & $\begin{array}{l}\text { Adanya teknologi informasi dan komunikasi membuat setiap pedesaan } \\
\text { menjadi daerah yang maju akan informasi. }\end{array}$ & 13 & 11 & 6 \\
\hline 5. & \multirow{3}{*}{$\begin{array}{l}\text { Penerapan teknologi di pedesaan sangat dibutuhkan. } \\
\text { Teknologi Informasi dan komunikasi akan menjadi suatu hal yang sangat } \\
\text { penting. } \\
\text { Salah satu teknologi informasi dan komunikasi yang berkembang pesat saat } \\
\text { ini adalah teknologi menggunakan media aplikasi dan internet yang dapat di } \\
\text { akses kapanpun dan dimanapun. }\end{array}$} & 29 & 1 & 0 \\
\hline 6. & & 26 & 4 & 0 \\
\hline 7. & & 19 & 10 & 1 \\
\hline 8. & \multirow{3}{*}{$\begin{array}{l}\text { Teknologi informasi dan komunikasi hadir dengan adanya Era Globalisasi. } \\
\text { Desa Ciakar merupakan desa yang sudah maju akan perkembangan } \\
\text { Teknologi informasi dan komunikasi. } \\
\text { Seluruh masyarakat desa Ciakar sudah dapat merasakan akan adanya }\end{array}$} & 18 & 10 & 2 \\
\hline 9. & & 1 & 14 & 15 \\
\hline 10. & & 1 & 13 & 16 \\
\hline
\end{tabular}




\begin{tabular}{|c|c|c|c|c|}
\hline No & Pernyataan & $\mathbf{S}$ & $\mathbf{R}$ & $\mathbf{T}$ \\
\hline 11. & $\begin{array}{l}\text { perkembangan Teknologi informasi dan komunikasi. } \\
\text { Dampak Teknologi informasi dan komunikasi yang pesat di Era Globalisasi } \\
\text { ini mampu membuat masyarakat desa Ciakar melek akan informasi. } \\
\text { Masvarakat senantiasa mencari tahu bagaimana kondisi vana teriadi di }\end{array}$ & 2 & 14 & 14 \\
\hline 12. & $\begin{array}{l}\text { negara Indonesia dengan memanfaatkan Teknologi informasi dan } \\
\text { komunikasi. }\end{array}$ & 6 & 14 & 10 \\
\hline
\end{tabular}

Hadirnya teknologi informasi dan komunikasi memudahkan manusia untuk mengakses segala sesuatu. Terkadang hal yang sulit dilakukan pun dapat dengan mudah dilakukan karena adanya teknologi. Dari 30 responden, memberikan pendapat bahwa $96,7 \%$ setuju dengan adanya teknologi memudahkan manusia dalam melakukan hal apapun, sedangkan $3,3 \%$ ragu-ragu akan adanya teknologi yang memudahkan manusia dalam melakukan hal apapun. Dapat disimpulkan bahwa saat ini manusia tidak akan terlepas dari teknologi, karena secara tidak langsung teknologi membantu aktivitas manusia. Perkembangan teknologi komunikasi dan informasi merupakan sebuah trend yang tidak dapat dibendung dan terbendung lagi. Era globalisasi telah mengantar perkembangan di berbagai aspek kehidupan manusia. Kehadiran teknologi komunikasi dan informasi dengan "segudang" kecanggihan dan kemudahan yang dibawanya mampu mengantar manusia ke sebuah tatanan yang memiliki kualitas dan standar hidup yang lebih baik. (Ahmad Amar, 2012: 149)

Teknologi informasi dan komunikasi perkembangannya sangat pesat. Tidak bisa dipungkiri bahwasanya kehadiran teknologi melesat dengan begitu cepat. Dengan perkembangan teknologi informasi yang demikian pesat masyarakat telah digerakkan dalam suatu transformasi sosial yang menuju suatu bentuk kehidupan baru yaitu 'era informasi'. Sebanyak $70 \%$ dari responden mengenai tanggapan setuju, bahwa kehadiran teknologi informasi dan komunikasi perkembangannya sangat cepat setuju, sedangkan $30 \%$ memberikan tanggapan ragu-ragu terhadap perkembangan teknologi yang sangat cepat. Serta perkembangan teknologi dan informasi yang semakin pesat telah mempengaruhi segenap kehidupan kita dalam berbagai bentuk aplikasi. (Rifqi Muntaqo, 2017).

Teknologi berkembang tidak hanya diperkotaan saja akan tetapi di pedesaan pun dapag dirasakan kehadiran serta perkembangannya. Namun, pedesaan tidak menutup kemungkinan bahwa perkembangan teknologinya cepat. Dalam pernyataan tersebut sebaanyak 30 responden memberikan tanggapan bahwa 3,3\% tidak setuju, $20 \%$ ragu-ragu, $76,7 \%$ tidak setuju. Sehingga dapat disimpulkan bahwa mereka tidak setuju jika pedesaan merupakan aspek yang perkembangan teknologinya cepat. Karena pada faktanya pedesaan merupakan salah satu aspek yang sulit mendapatkan akses akan adanya teknologi informasi. Sejak pemerintah Indonesia mengembangkan infrastruktur internet pada tahun 1980-an, jumlah pengguna internet terus meningkat, hingga tahun 2013 terdapat 71.19 juta pengguna internet di Indonesia. Dengan jumlah tersebut, penetrasi internet di Indonesia tahun 2013 adalah sebesar 28\%, walaupun angka penetrasi terus mengalami peningkatan, namun pengguna internet di Indonesia tidak merata secara geografis. (Robby Darwis Nasution, 2016: 38).

Saat ini, banyak pedesaan yang maju dalam mendapatkan akses informasi itu disebabkan dengan adanya perkembangan teknologi informasi dan komunikasi. Dari 30 responden memberikan pandangan bahwa sebanyak $43,3 \%$ setuju, $36,7 \%$ ragu-ragu, dan sebanyak $20 \%$ tidak setuju akan adanya teknologi informasi dan komunikasi yang memberikan dampak suatu pedesaan menjadi maju akan informasi. Saat ini, di Indonesia dapat kita saksikan begitu besar pengaruh kemajuan teknologi terhadap nilai-nilai kebudayaan yang di anut masyarakat, baik masyarakat perkotaan maupun pedesaan (modernisasi). Kemajuan teknologi seperti televisi, telepon dan telepon genggam (HP), bahkan internet bukan hanya melanda masyarakat kota, namun juga telah dapat dinikmati oleh masyarakat di pelosok - pelosok desa. Akibatnya, segala informasi baik yang bernilai positif maupun negatif, dapat dengan mudah di akses oleh masyarakat. Dan di akui atau tidak, perlahan-lahan mulai mengubah pola hidup dan pola pemikiran masyarakat khususnya masyarakat pedesaan dengan segala image yang menjadi ciri khas mereka. (Hendro Setyo Wahyudi dan Mita Puspita Sukmasari, 2014: 21).

Penerapan teknologi di pedesaan sangat dibutuhkan. Pernyataan ini diajukan untuk melihat tingkat kebutuhan akan teknologi di pedesaan khususnya di desa Ciakar. Dari hasil 
kuesioner dapat di lihat bahwa sebanyak 96,7\% responden merasa setuju dan 3,3\% saja responden yang merasa ragu-ragu akan pernyataan tersebut. Hal ini dapat disimpulkan bahwa penerapan teknologi di pedesaan memang sangat dibutuhkan apalagi di desa-desa terpencil. Istilah teknologi dapat mencakup dua hal. Pertama, teknologi menunjuk pada peralatan, yaitu unsur yang digunakan untuk menyelesaikan tugas. Kedua, keterampilan atau prosedur yang diperlukan untuk membuat dan menggunakan peralatan tersebut (Muhammad Ngafifi, 2014:36)

Teknologi informasi dan komunikasi akan menjadi suatu hal yang sangat penting. Pernyataan ini diajukan agar peneliti tau seberapa pentingnya Teknologi informasi dan komunikasi untuk masyarakat desa ciakar. Dari hasil kueosioner menunjukan $86,7 \%$ responden merasa setuju, sedangkan $13,3 \%$ responden merasa ragu-ragu dengan pernyataan tersebut. Hal ini membuktikan bahwa Teknologi informasi dan komunikasi itu adalah salah satu hal yang penting khususnya di desa ciakar, purwakarta. Teknologi informasi dan komunikasi memiliki beberapa komponen utama yang mendukungnya. Komponen-komponen yang mendukung teknologi informasi dan komunikasi diantaranya adalah komputer (sistem komputer), komunikasi, dan keterampilan bagaimana menggunakannya (Jamal Ma'mur Asmani, 2011: 107).

Salah satu teknologi informasi dan komunikasi yang berkembang pesat saat ini adalah teknologi menggunakan media aplikasi dan internet yang dapat di akses kapanpun dan dimanapun. Pernyataan ini diajukan untuk mengetahui apakah media yang berkembang pesat saat ini adalah media aplikasi dan internet atau media yang lainnya. Dari hasil kuosioner menunjukan bahwa $63,3 \%$ responden memilih setuju, 33,3\% responden menjawab ragu-ragu, dan 3,4\% responden memilih tidak setuju. Hal ini dapat disimpulkan bahwa sebagian teknologi informasi dan komunikasi yang berkembang pesat saat ini adalah media aplikasi dan internet yang mana media tersebut dapat diakses kapanpun dan dimanapun. Era perkembangan komputerisasi terus berlanjut dan berkembang sampai pada tahun 1990-an sehingga melahirkan teknologi internet. Para ahli tercengang dengan begitu pesat perkembangan teknologi ini yang oleh mereka disebut "sebagai yang tidak terduga". Internet begitu memukau dan begitu cepat berkembang dengan varian-varian programnya yang menjadikan bumi ini dalam cengkraman tekonologi (Kholil, 2011: 24).

Teknologi informasi dan komunikasi hadir dengan adanya Era Globalisasi. Pernyataan ini diajukan untuk mengetahui apakah hadirnya TIK benar ketika adanya Era Globalisasi atau bahkan sebaliknya. Dari hasil kuosioner menunjukan bahwa $60 \%$ responden menyatakan setuju, 33,3\% responden menyatakan ragu-ragu, dan $6,7 \%$ responden menyatakan tidak setuju akan pernyataan tersebut. Hal ini dapat disimpulkan bahwa memang benar Teknologi informasi dan komunikasi hadir dengan adanya Era Globalisasi, karena menurut data yang telah didapat lahirnya era globalisasi yaitu pada abad ke-19 atau sekitar tahun 1801-1900. Sedangkan hadirnya Teknologi informasi dan komunikasi atau munculnya istilah TIK yaitu pada pertengahan abad ke-20. Teknologi komunikasi merupakan alat yang menambah kemampuan orang berkomunikasi, sedangkan teknologi informasi adalah pengerjaan data oleh komputer dan telekomunikasi. Ini berarti tekonologi komunikasi memiliki perbedaan dalam titik berat perhatian. Kenyataan inilah yang mendorong seorang ahli komunikasi, Andrea Hardjana, menggunakan istilah tekonologi informasi dan komunikasi (Abrar, 2003: 4).

Pernyataan selanjutnya yaitu Desa Ciakar merupakan desa yang sudah maju akan perkembangan Teknologi Informasi dan Komunikasi yang memiliki hasil 3,3\% responden memilih setuju. Sedangkan ragu-ragu sebanyak $42,5 \%$ dan tidak setuju sebanyak $51,5 \%$. Jadi dapat disimpulkan bahwa ternyata masih banyak masyarakat yang ragu dengan pernyataan tersebut. Apalagi yang berpendapat tidak setuju lebih banyak. Maka dari itu memang masyarakat daerah Desa Ciakar masih meragukan bahwa desa nya adalah desa yang maju akan ICT. Ternyata penyebaran ICT belum sepenuhnya menyebar keseluruh wilayah pedesaan di Indonesia salah satunya yaitu Desa Ciakar ini. Pernyataan tersebut tidak disetujui karena memang masih banyak masyarakat desa Ciakar yang belum mengetahui perkembangan TIK yang ada di negara kita.

Seluruh masyarakat Desa Ciakar sudah dapat merasakan akan adanya perkembangan ICT. Pernyataan tersebut memiliki hasil bahwa masyarakat tidak setuju memiliki jumlah $53,5 \%$. Sedang yang meragukan pernyataan tersebut sebanyak $43,3 \%$ dan yang setuju sebanyak $3,4 \%$. Jadi dapat disimpulkan bahwa masyarakat Desa Ciakar belum sepenuhnya merasakan perkembangan akan adanya ICT didaerahnya. Disini mereka tentu saja mengharapkan ICT ada 
dan tersebar merata didaerahnya. Disini masyarakat yang merasakan cenderung orang-orang yang sudah pernah berpengalaman keluar kota dan merasakan bahwa memang perkembangan TIK didesa sangat berbeda dengan yang dikota.

Dampak Teknologi Informasi dan Komunikasi yang pesat di Era Globalisasi ini mampu membuat desa Ciakar melek akan informasi. Pernyataan tersebut memiliki hasil seimbang antara ragu sebanyak $46,7 \%$ dengan tidak setuju $46,7 \%$. Sedangkan responden yang setuju sebanyak $6,7 \%$. Jadi dapat disimpulkan bahwa memang masih banyak masyarakat yang meragukan bahkan tidak setuju bahwa memang ICT belum mampu membuat masyarakat desa Ciakar melek akan perkembangan ICT. Menurut Fathoni (2010), upaya yang bisa dilakukan untuk meningkatkan kualitas hidup masyarakat pedesaan yaitu perlunya memperhatikan beberapa hal diantaranya membangun komitmen pemerintah terhadap pemanfaatan TIK di pedesaan, pendekatan pengenalan, dan pemanfaatan TIK dari sekolah serta membangun kemitraan dengan industries dan jasa telekomunikasi. Nah disini bisa dilihat jika kita melakukan hal tersebut mungkin saja desa Ciakar akan melek akan informasi yang diterima.

Pernyataan yang terakhir "Masyarakat senantiasa mencari tahu bagaimana kondisi yang terjadi di negara Indonesia dengan memanfaatkan Teknologi informasi dan komunikasi." Nah disini responden yang menjawab setuju hanya $20 \%$ saja, sedangkan yang tidak setuju sebanyak $33,3 \%$ kebanyakan responden menjawab ragu-ragu dengan jumlah 46,7\%. Dari sini jelas sekali bahwa memang masyarakat desa Ciakar belum sepenuhnya mencari tahu apa yang sedang menjadi perbincangan di negara kita. Mereka yang mencari tahu pun masih sangat sedikit. Hal ini diakibatkan memang penyebaran akses internet yang kurang merata di negara kita. Dimana akses internet cepat lebih didominasi oleh daerah perkotaan. Robby DN (2016), menyatakan bahwa keterbukaan akses informasi dan transfer Teknologi dari negara maju kepada negara berkembang seperti Indonesia merupakan ciri masuknya era Globalisasi. Pernyataan tersebut jelas sekali, bahwa memang penyebaran informasi terharu belum dapat diketahui oleh masyarakat daerah pedesaan khususnya desa Ciakar ini.

Setelah dianalisis dari hasil penelitian tersebut, peneliti menyimpulkan bahwa dengan adanya Teknologi Informasi dan Komunikasi itu sangat memudahkan masyarakat untuk mengakses atau mencari tahu apapun terutama tentang informasi, dari situ dapat dilihat bahwa Teknologi Informasi dan Komunikasi memang sangat dibutuhkan bukan hanya di kota-kota besar tetapi juga di desa-desa karena teknologi informasi dan komunikasi sudah menjadi hal yang sangat penting di masa sekarang bahkan hingga nanti dan salah satu teknologi informasi dan komunikasi yang berkembang pesat saat ini adalah teknologi menggunakan media aplikasi dan internet dimana itu semua dapat di akses kapanpun dan dimanapun.

\section{KESIMPULAN}

Dari permasalahan diatas dapat disimpulkan bahwa perkembangan teknologi, informasi dan komunikasi di Indonesia masih belum mengalami kemerataan. Dimana perkembangan TIK hanya diperoleh oleh daerah-daerah kota saja. Berbeda dengan daerah pedesaan yang masyarakat-nya masih tertinggal akan perkembangan TIK. Selain itu, layanan informasai di Indonesia juga masih lemah dan minimnya informasi yang bersifat edukatif dengan banyaknya tayangan yang belum mencerdaskan serta memberi dampak baik untuk masyarakat secara umum.

Hasil dari penelitian yang telah kami lakukan didapat bahwa masyarakat desa Ciakar mengetahui akan pentingnya melek ICT pada masyarakat didesanya. Mereka juga berpendapat bahwa pedesaan bukanlah daerah yang perkembangan teknologinya cepat. Mereka merasa bahwa ketidakmerataan akan ICT membuat masyarakat desa Ciakar tertinggal banyak akan kemajuan ICT, dan mereka berharap dapat segera ikut serta dalam kemajuan ICT yang ada. Selain itu, masyarakat desa Ciakar juga seringkali tidak mencari tahu bagaimana kondisi yang yang terjadi negara kita karena minimnya arus informasi yang didapat. Mereka berharap agar pemerintah mampu membuat masyarakat daerah pedesaan mampu melek akan ICT.

Pentingnya melek teknologi, informasi dan komunikasi di pedesaan sangat diperlukan, negara kita tertinggal sangat jauh dengan negara berkembang lainnya. Ada beberapa sektor yang mendukung perkembangan teknologi. Diantaranya aksesibilitas, pertanian, perubahan iklim, pendidikan dan kesehatan. Hal yang bisa dilakukan aparat pemerintah dalam melakukan perubahan pada perkembangan di pedesaan bisa dengan cara mempersiapkan infrastruktur teknologi yang memadai secara merata serta memperkuat jaringan internet untuk masyarakat di 
pedesaan. Infrastruktur teknologi yang memadai membuka peluang bagi masyarakat untuk meningkatkan penguasaan dan pemanfaatan teknologi. Infrastruktur teknologi juga menjamin setiap orang untuk terhubung ke dalam jaringan. Dengan demikian, peluang untuk memanfaatkan akses pada ekonomi digital semakin terbuka.

\section{Referensi}

Abrar, A.N., (2003). Teknologi Komunikasi Perspektif Ilmu Komunikasi. Yogyakarta: LESFI.

Ahmad, Amar (2012). Perkembangan Teknologi Komunikasi dan Informasi Akar Revolusi dan berbagai Standarnya. Jurnal Dakwah Tabligh, 13(1):149.

Angga, Boy. (2020). Ekonomi Digital dan Ketimpangan Literasi Teknologi. Diakses pada tanggal 03 Desember 2020 dari https://news.detik.com/kolom/d-4859789/ekonomi-digital-dan-ketimpangan-literasiteknologi

Appadurai, Arjun. (2006). "The Right To Reseach." Globalisation, Societies dan Education (The New School), 2006: 167-177.

Battersby, Paul, and Joseph M. Siracusa. (2009). Globalization and Human Security. United States of America: Royman and Little Field Publisher.

Bratadharma, Angga (2020). Perkembangan Teknologi Berperan Besar Dorong Pertumbuhan Ekonomi. Diakses pada tanggal 02 Desember 2020 dari https://m.medcom.id/ekonomi/bisnis/ObzZY1Ybperkembangan-teknologi-berperan-besar-dorong-pertunbuhan-ekonomi

Castells, M. (1999). Information Technology, Globalization and Social Development. UNRISD Discussion Paper, 111-114.

Fathoni. (2010). Strategi Implementasi Teknologi Informasi dan Komunikasi untuk Meningkatkan Kualitas Hidup Masyarakat Pedesaan di Indonesia.Seminar Nasional VI, 3 Juli 2010, Yogyakarta.

Kholil, S., (Ed), (2011). Teori Komunikasi Massa. Bandung: Ciptapustaka Media

Jamal Ma'mur Asmani. (2011). Tips Efektif PemanfaatanTeknologi Informasi dan Komunikasi dalam Dunia Pendidikan. Yogyakarta: Diva Press.

Kurniawan, Borni. Desa Mandiri, Desa Membangun. Jakarta: Kementerian Desa, Pembangunan Daerah Tertinggal, dan Transmigrasi Republik Indonesia, 2015.

Liliweri, A., (2009). Dasar-Dasar Komunikasi Antarbudaya. Yogyakarta: Pustaka Pelajar Offset.

Nasution, Robby.D. (2015). "MENEROPONG MASA DEPAN PENDIDIKAN DI INDONESIA (Penerapan Virtual Learning di Indonesia)." PROSIDING SEMINAR NASIONAL PENDIDIKAN. Ponorogo: FKIP Universitas Muhammadiyah Ponorogo, 2015. 485-489.

Mareta, Anastasia. "Dampak Positif dan Negatid Teknologi Komunikasi dan Informasi." http://komunikasi.us. Mei 12, 2014. http://komunikasi.us/index.php/cou rse/perkembangan-teknologikomunikasi/1579dampak-positif- dan-negatif-perkembanganteknologi-komunikasi-daninformasi (accessed Juni 12, 2014).

Marius, Parlindungan, and Sapto. Profil Pengguna Internet Indonesia 2014. Jakarta: Asosiasi Penyelenggara Jasa Internet Indonesia, 2015.

Muhammad Ngafifi, Kemajuan Teknologi Dan Pola Hidup Manusia Dalam Perspektif Sosial Budaya, Jurnal Pembangunan Pendidikan: Fondasi dan Aplikasi Vol. 2, No. 1, 2014, 34-36.

Nasution, Robby Darwis (2016). Pengaruh kesenjangan digital terhadap pembangunan Pedesaan (Rural Development). Jurnal Penelitian Komunikasi dan Opini Publik, 2(1):38.

Nasution, R.D. (2016). Pengaruh Kesenjangan Digital Terhadap Pembangunan Pedesaan (Rural Development). Jurnal Penelitian Komunikasi dan Opini Publik, 20(1), 31-44.

Rifai M. (2017). Teknologi Informasi Dan Komunikasi Dalam Perkembangan Budaya Masyarakat. Jurnal PPKM I. 2017: 12-20.

Ruseffendi, H. E. T. (2010). Perkembangan pendidikan matematika. Jakarta: Universitas Terbuka.

Sitompul, RF. 2009. Merancang Model Pengembangan Mayarakat Pedesaan dengan Pendekatan System Dynamics. Jakarta (ID): LIPI Press.

Sugiyono. (2017). Metode Penelitian Kuantitatif, Kualitatif, dan R\&D. Bandung : Alfabeta, CV. 